\title{
Using hexagonal grids and network analysis for spatial accessibility assessment in urban environments - a case study of public amenities in Toruń
}

\begin{abstract}
Spatial accessibility is one of fundamental problems of geography, and transport geography in particular. It is one of the key factors affecting the ability to use certain services by the residents of a given area. Therefore, it is important to develop appropriate methods for the analysis of spatial accessibility. This paper describes a methodology for analyzing spatial accessibility in urban areas using a hexagonal grid combined with a network analysis. The proposed methodology is applied to the city of Toruń, Poland. Spatial distribution of accessibility to selected public amenities is analyzed and areas of high and low accessibility are identified. Finally, a prototype of a novel web-based system is proposed to allow citizens and city officials to perform custom analysis based on individual preferences.
\end{abstract}

\section{Keywords}

Hexagonal grid • spatial accessibility $\cdot$ urban accessibility $•$ network analysis $\cdot$ travel time

(C) University of Warsaw - Faculty of Geography and Regional Studies
Jan Burdziej

Department of Geomatics and Cartography Faculty of Earth Sciences

Nicolaus Copernicus University in Toruń, Poland

e-mail: jan.burdziej@gmail.com
Introduction

Spatial accessibility is one of the fundamental problems of geography, and transport geography in particular (Weber 2006). It determines how easy it is to reach certain places (Burdziej 2016), thus it is one of the key factors affecting the ability of the citizens of a given area to use certain services (Kwan \& Weber 2008). It is argued that better accessibility reduces the time spent on commuting (Osborne 2014), which in turn means lower costs of living and improved quality of life and the environment (Doi et al. 2008; Lotfi \& Koohsari 2009; Nelson 2008; Perkins et al. 2004; Somarriba \& Pena 2008). The importance of spatial accessibility has been considered by many regional, national and international strategic studies (Komornicki et al. 2008; Nelson 2008; Rosik 2012; Salonen 2014; Spiekermann \& Neubauer 2002; Vandenbulcke et al. 2009).

Daily commutes are increasing. It has been estimated that in 2003, car drivers in Belgium wasted 13 million hours due to congestion, which represented a cost of $€ 150$ million (Vandenbulcke et al. 2009). Another study from Poland (Pifczyk 2014) estimated that the average daily commute between home and work takes 77 minutes, which is equivalent to nearly 300 hours per year. Moreover, the report from the UK's Office for National Statistics reveals that commuters are less satisfied and happy when compared with those working from home and each extra minute travelled by commuters makes them less satisfied and more anxious (Osborne 2014). Longer commutes not only affect citizens' well-being, they also have a negative impact on traffic congestion, the urban environment and the condition of roads.

In this paper, commuting is regarded as general mobility within urban areas. However, it is worth noting that daily commutes and other periodically recurring travels have the greatest impact on urban traffic and the overall quality of life.
There are many reasons for daily commuting, but some of the most important are: work (Taylor 1999), school (Guzik 2003a; Guzik 2003b; Tang et al. 2017), shopping (Farber et al. 2014; Larsen \& Gilliland 2008), healthcare (Balfour \& Allen 2014; Fransen et al. 2015; Guagliardo 2004; Kuhlthau 2011; Luo \& Wang 2003; McGrail \& Humphreys 2014a; Neutens 2015; Rosero-Bixby 2004; Stępniak 2013; Yiannakoulias et al. 2013), and entertainment, sport and recreation (Beler 1997; Billaudeau et al. 2011; Chiesura 2004; Comber et al. 2008). Interestingly studies have also been carried out on the accessibility of the public transport system, such as bus stops and metro stations (Kraft 2016; Zhu \& Liu 2004). The spatial accessibility to all these locations (called in this paper 'Points of Interest', 'POIs' or 'Destinations') impacts our daily travel times. When moving to a new location (i.e. relocating), the accessibility to all desired POls must be evaluated. This requires identifying specific POls in the neighbourhood, measuring travel time from the potential new location to these facilities and undertaking a complex multicriteria decision-making process. This is troublesome even for one location, not to mention comparing several different locations. However, as other studies show (Burdziej 2009), in some cases even a slightly different location may have significantly different accessibility, resulting in high impact on our daily lives. Thus, there is a great need for decision support tools that can help citizens assess potential locations. Although there might be different motivations for relocation (Lopez \& Greenlee 2016) and many factors that influence decisions regarding where to buy or rent a property, it is spatial accessibility to selected urban services which often plays a key role.

Furthermore, for local decision makers and city planners, it is important to evaluate the distribution of existing and planned 


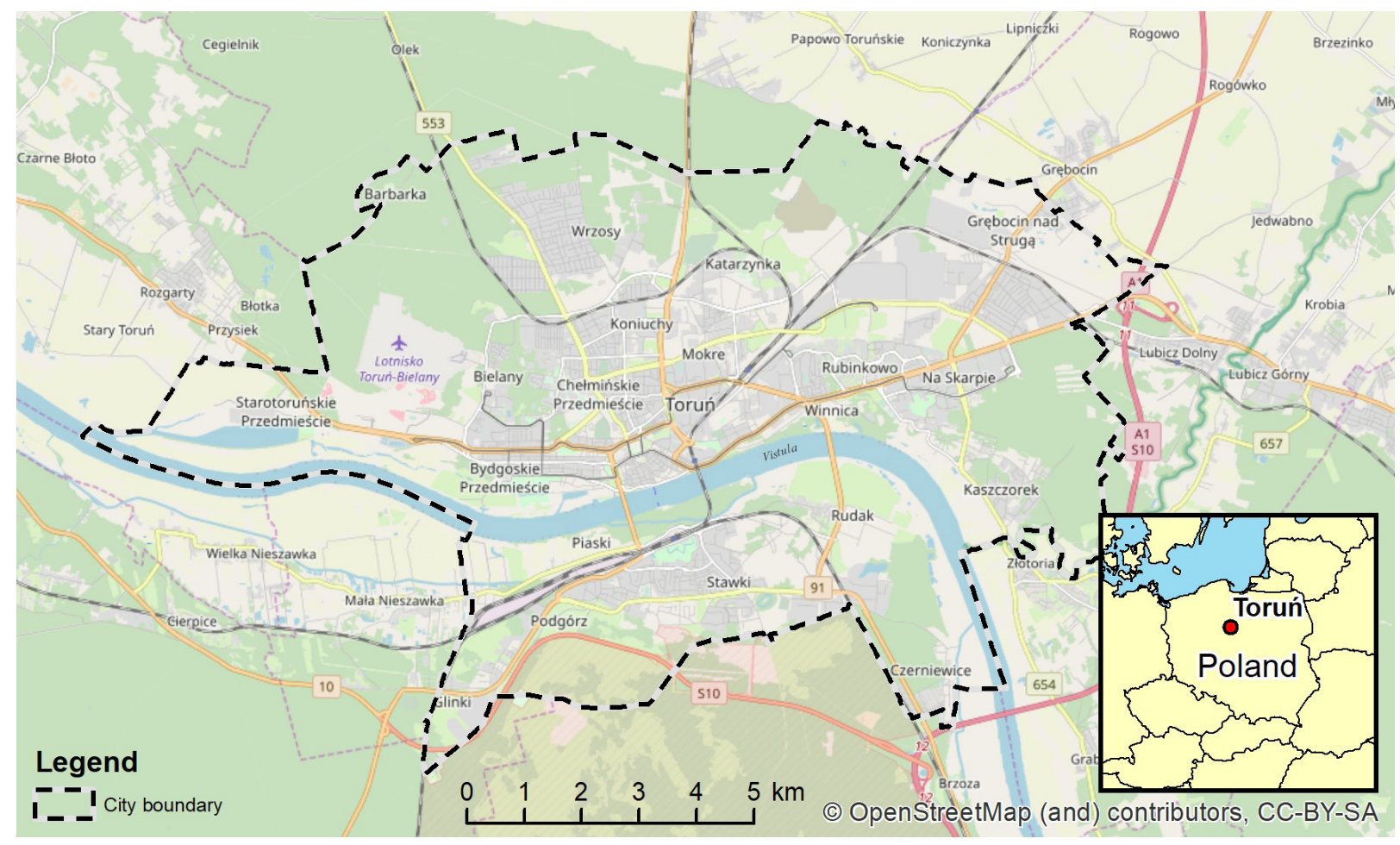

Figure 1. Study area - city of Toruń (source: own elaboration)

facilities (such as health centres and preschools) with respect to the distribution of the population. These analyses should help them ensure an equal level of spatial accessibility to different amenities and services for all citizens, which eventually contributes to the sustainable development of the city.

Measuring accessibility has a long history (Galton 1881; Penck 1887). However, the complexity of this topic has constantly raised new challenges related to spatial scales, temporal dynamics and accessibility measures (Hodge 1997). In fact, many recent scientific studies have focused on developing new methods and measures of accessibility (Bielecka \& Filipczak 2010; Burdziej 2016; Fransen et al. 2015; McGrail \& Humphreys 2014b; Wang et al. 2014; Weber 2006; Zhu, Liu, \& M. C. Yeow 2006).

This paper presents a methodology for analysing spatial accessibility in an urban environment using network analysis and a grid of hexagonal sampling fields. The proposed methodology is applied to the city of Toruń, located in central Poland (Fig. 1). The city has an area of 115 square kilometres and approximately 200,000 inhabitants. The spatial distribution of accessibility was analysed and areas of high and low accessibility were identified. Finally, a prototype of a novel web-based system is proposed to allow citizens, city planners and decision makers to perform custom analyses based on custom parameters and individual preferences.

\section{Methods}

Preparing sampling grid

The proposed methodology for the analysis of spatial accessibility to public amenities in Torun is based on network analysis used to find the shortest routes between a grid of Origins distributed evenly within the city area and selected Destinations representing different public amenities.

The analysis was conducted in a hexagonal grid of sampling fields, which covers the whole city area. Each sampling field is a hexagon with an area of approximately 2.6 hectares and a side length of $100 \mathrm{~m}$. The whole grid consists of 4,693 sampling fields. The centre of each hexagon is an Origin and a starting point for calculating the shortest routes to all Points of Interests (Destinations).

The hexagonal sampling grid allows better distribution of sampling points (centroids of each hexagon) with approximately $30 \%$ fewer grid cells compared to a similar grid of squares (Fig. 2). The hexagonal shape also ensures that the distance from the centre to the edges is more equal than in the case of squares. This type of grid has proved to be more suitable in various types of research (Birch et al. 2007; Carr et al. 1992; Levine \& Feinholz 2015). It has also been used in the context of spatial accessibility analysis (Cabrera-Barona et al. 2016; Zhu, Liu, \& M. C Yeow 2006; Zhu, Liu, \& M. C. Yeow 2006; Zhu \& Liu 2004).

\section{Building a POI database}

The next step was to define a list of categories of the public amenities for which spatial accessibility would be analysed. Public amenities fulfilling the following criteria were selected and grouped into 16 distinct categories:

1. they play an important role in daily commuting for a large number of citizens,

2. they are essential in terms of quality of life and fulfilling some citizens' key needs,

3. they are publicly available.

It was important to ensure that all objects within each category provided a similar set of services and values for all citizens. Based on this requirement, it was possible to include preschools or primary schools (each unit provides comparable services), whereas vocational schools had to be excluded from the analysis, since they might provide a significantly different profile of education. The same criterion allowed the inclusion of Primary Health Care Centres (POZ), and enforced the exclusion of hospitals and private medical practices, since dental services cannot be treated equally to orthopeadic surgery clinics, etc. 

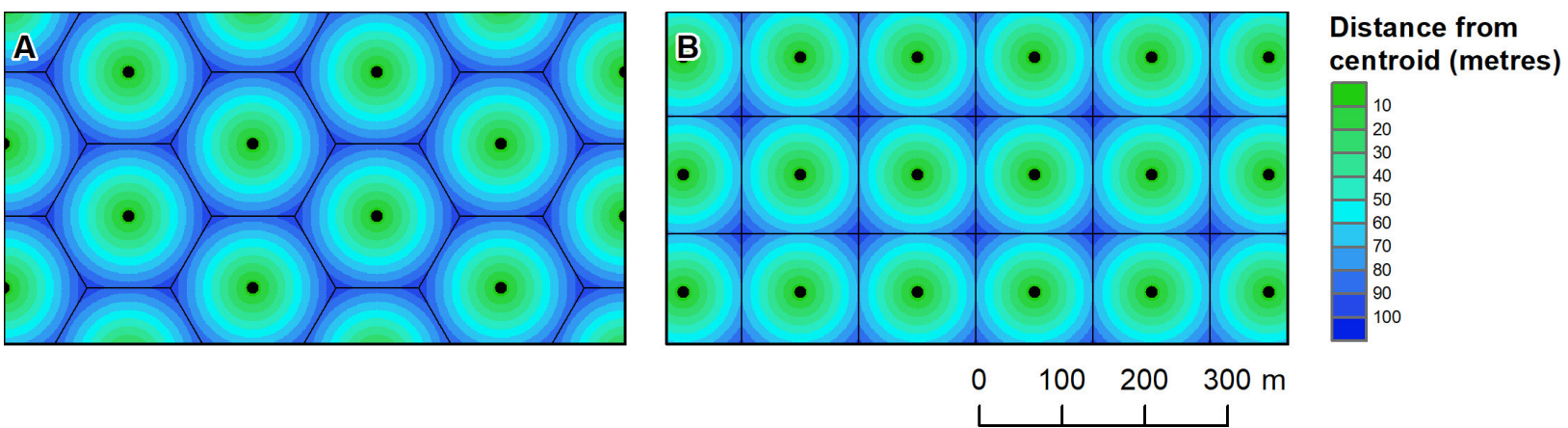

Figure 2. Comparison of the spatial efficiency of hexagonal $(A)$ vs. square grids $(B)$ (source: own elaboration)

The research was limited to amenities located within the administrative boundaries. However, it would be interesting to include the facilities located in suburban areas, which can often provide services for peripheral urban areas as well. Such as analysis might contribute to a better understanding of the relationship between the city and its suburbs (Hołowiecka \& Szymańska 2008).

Forest areas and urban green spaces were modelled as points spaced evenly along their boundaries at a distance of 100 $\mathrm{m}$. Each such point was regarded as a destination point, as most of the green areas in Torun are not fenced and can be accessed from all sides.

Finally, a POI database comprising a total of 1,990 public amenities was created. They were grouped into 16 categories: preschools, elementary schools, middle schools, high schools, clinics, sports fields and sports halls, swimming pools, tennis courts, local shops and supermarkets, shopping centres, cinemas and theatres, museums, churches, public transport stops, green areas and the city centre (represented by a single point located in the traditional city centre).

\section{Building a road network model}

Network analysis requires a detailed road network model that can be used for automated routing. In the proposed methodology, an open source dataset from the Open Street Map project was used. Initially, the raw OSM data was downloaded using the Overpass API online service. The data was acquired in OSM XML format, consisting of nodes, ways and relations (OpenStreetMap Wiki | OSM XML 2015). These elements can be used to model the whole road network, including turn restrictions, speed limits, street direction, etc.

Next, the OSM data was transformed into a Network Dataset using a free ArcGIS plugin called ArcGIS Editor for OpenStreetMap (Zimmermann 2010). Further steps included data validation and error correction. All the identified errors in the OSM dataset, such as road segment disconnectivity, incorrect road direction, and so on, had to be corrected manually in order to ensure that spatial accessibility could be calculated for all sampling fields. One of the major advantages of OSM data over commercial data sources and services (such as Google Maps) is that OSM data can easily be corrected by anyone. There is also a vibrant online community of OSM volunteers who assess all the changes and ensure that the database is error-free.

The validation of the road network model developed using Network Analyst (ARCGIS) was conducted by comparing its results with three other routing services: Google Maps (GMAPS), Bing (BING) and Open Source Routing Machine (OSRM). Twelve test routes were established and routing times, as well as calculated route geometries, were compared (Fig. 3).
Calculating accessibility using Model Builder

For all the hexagon centroids (Origins), the shortest route to each POI (Destination) was calculated using a Python-based model developed in the ArcGIS Model Builder environment (Fig. 4). Additionally, the distances between the Origin and Destination points and their closest network segments were measured and added to each shortest route. This was especially important for Origins, as some of them (e.g. those within the urban forest areas) were located up to $860 \mathrm{~m}$ from the nearest public road.

The majority of routing services project Origin and Destination coordinates onto their nearest road segments, and routing algorithms are only applied to the road network. The distance between initial locations and their nearest road segments is usually not counted, although in some cases it may significantly affect calculated travel times (Fig. 5).

In order to avoid the underestimation of travel times, the shortest route was adjusted based on the distance from the Origin and Destination to the nearest road segment. This distance was converted to travel time assuming an average walking speed of 4 $\mathrm{km} / \mathrm{h}$. As a result, the final travel time consisted of:

1. travel time from the Origin to the nearest road network segment,

2. transit time (calculated using ArcGIS Network Analyst, based on Open Street Map data and assuming car driving mode);

3. travel time from the Destination to the nearest road network segment.

The accessibility was calculated as travel time (in minutes) from each of the 4,693 Origins to all of the 1,990 Destinations. This resulted in a total of $9,339,070$ routes. For each, several parameters were recorded: route distance, travel time, distances from the Origin and Destination to the nearest road segment, total travel time, IDs of Origins and Destinations, and the Destination category.

Based on the network analysis, the nearest POls in each category and their respective shortest travel times were recorded and assigned to each hexagon. Maps and accessibility statistics were developed for each POI category and the spatial variation of accessibility was then analysed.

Service (or catchment) areas are fundamental concepts when analysing spatial accessibility (Fransen et al. 2015; Jia 2016; McGrail \& Humphreys 2014b; Steppniak 2013; Wang et al. 2014). They define how far each facility can effectively deliver its services (McGrail \& Humphreys 2014b). In this paper, the exclusive service areas were delineated by identifying the ID of the nearest POI from a selected category (Fig. 9). 

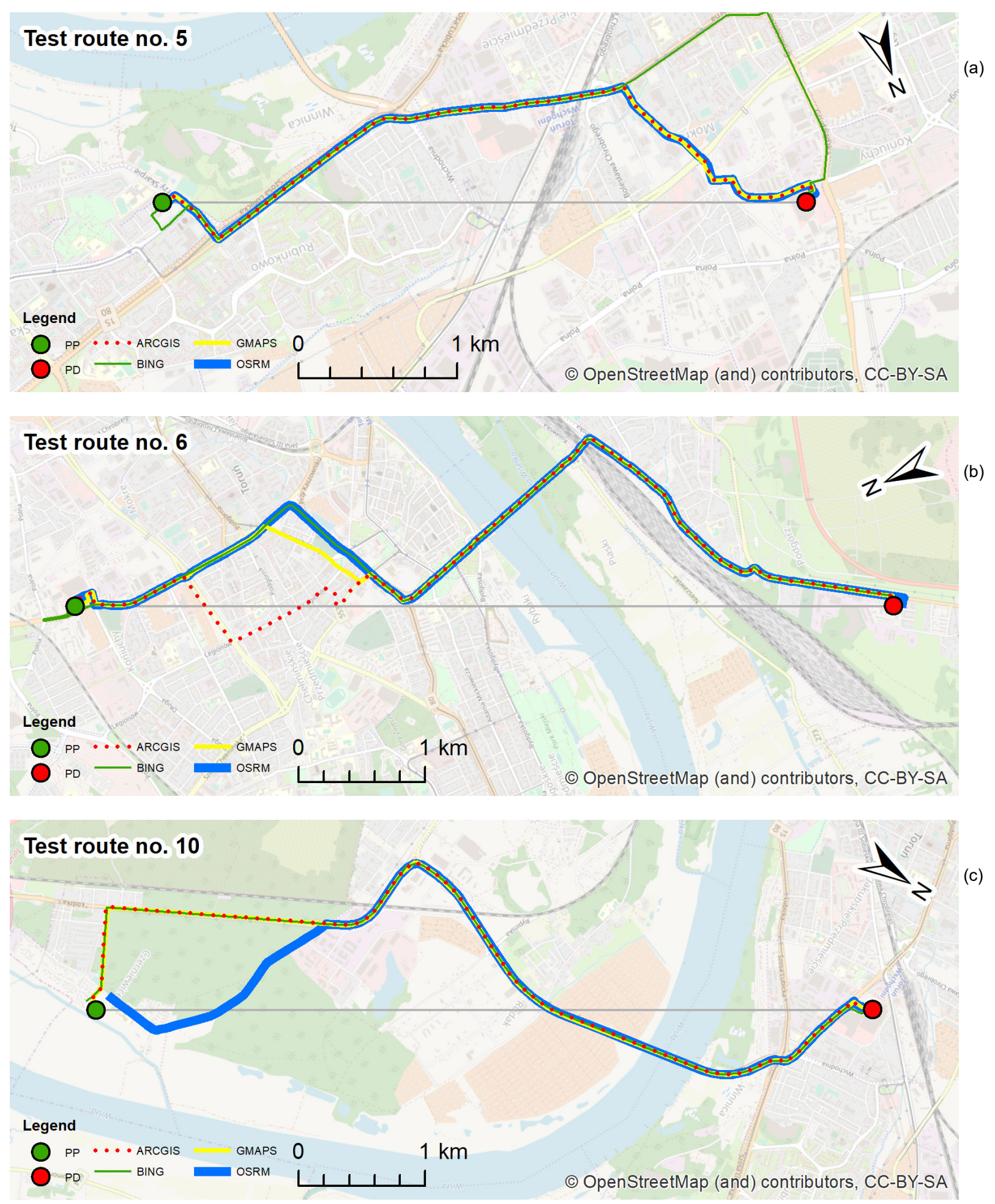

Figure 3. Comparison of sample test routes calculated using various routing services (source: own elaboration) 


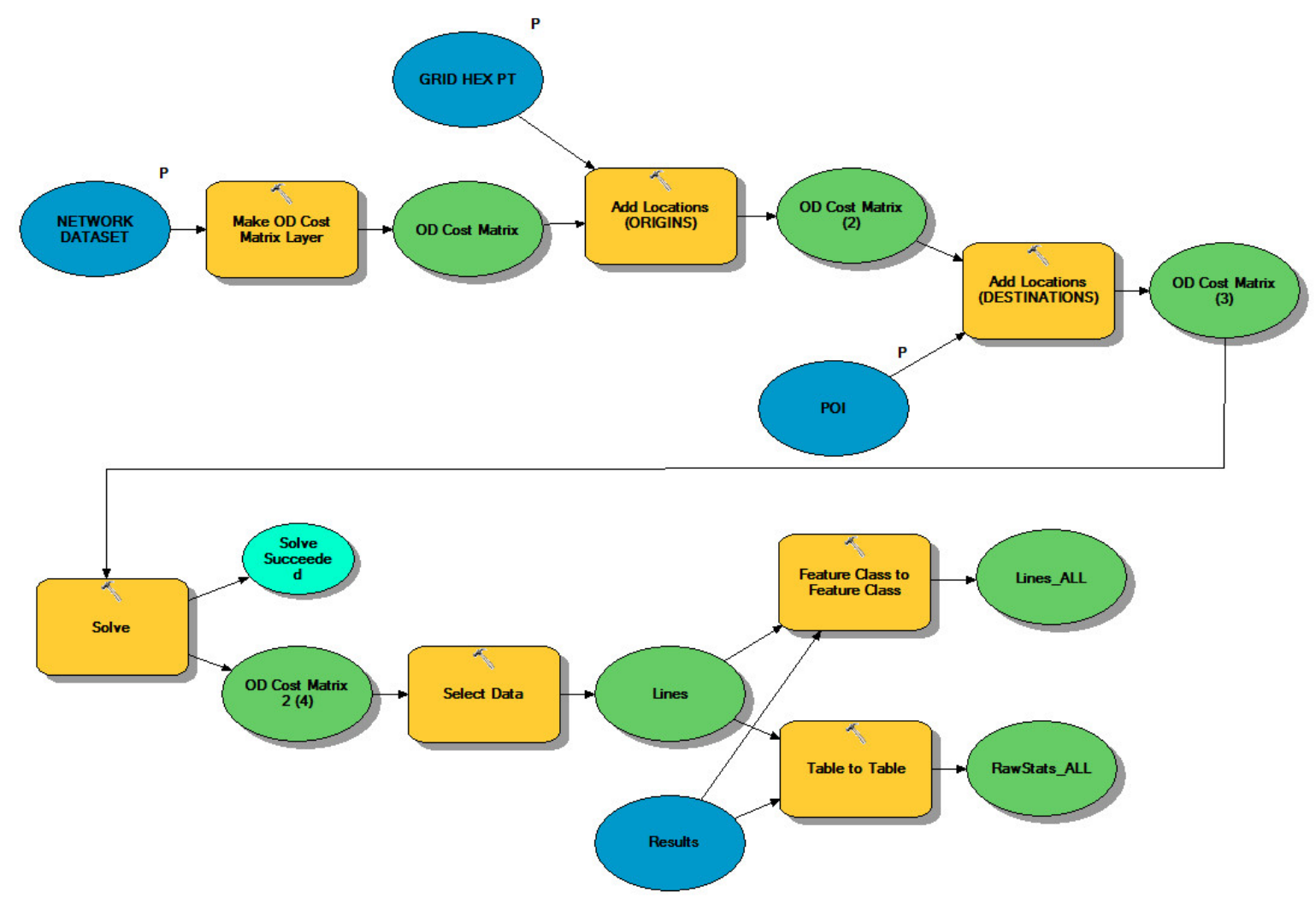

Figure 4. Accessibility analysis model (source: own elaboration)

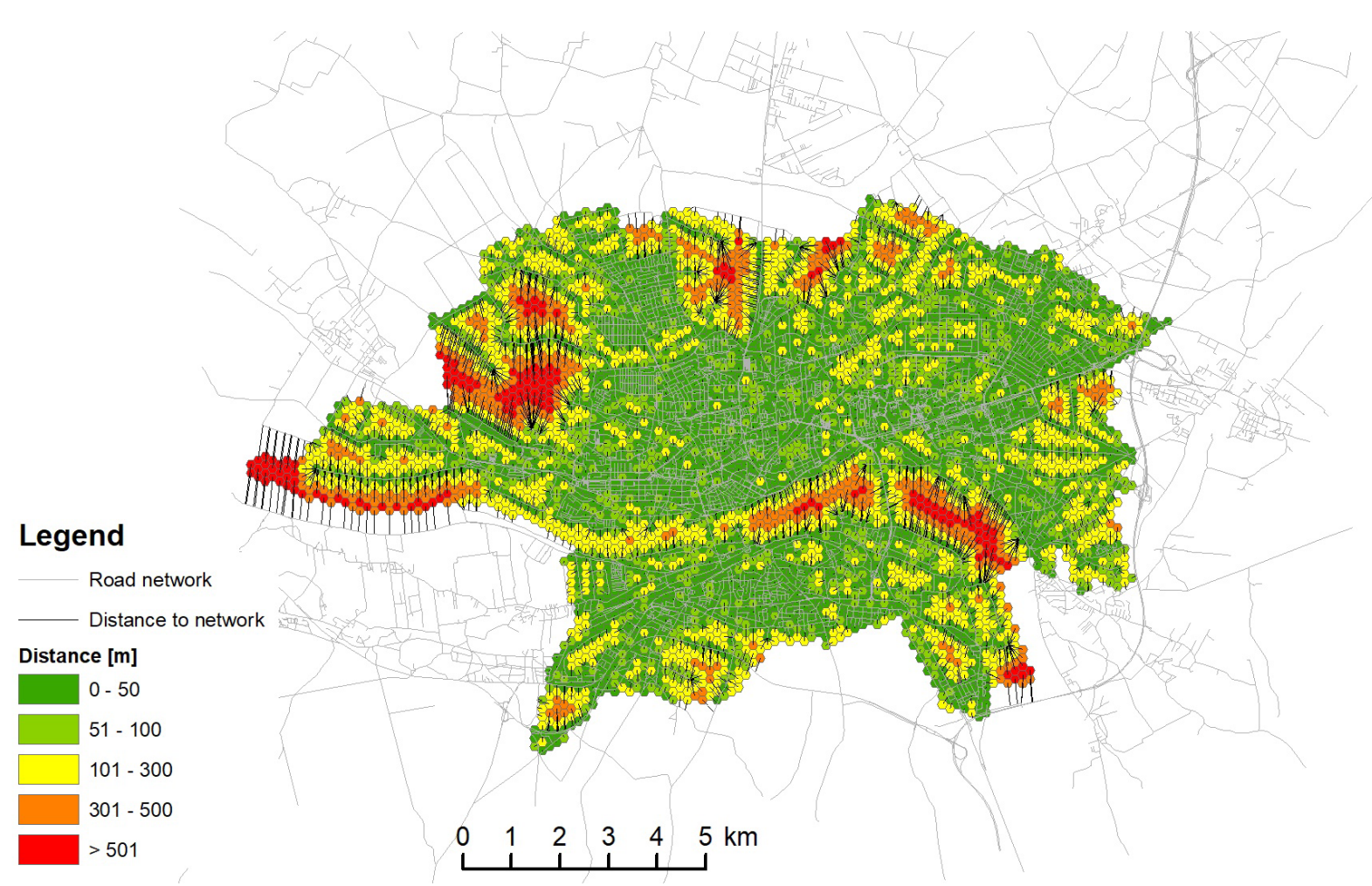

Figure 5. Distance from Origins to their nearest road segment (source: own elaboration) 


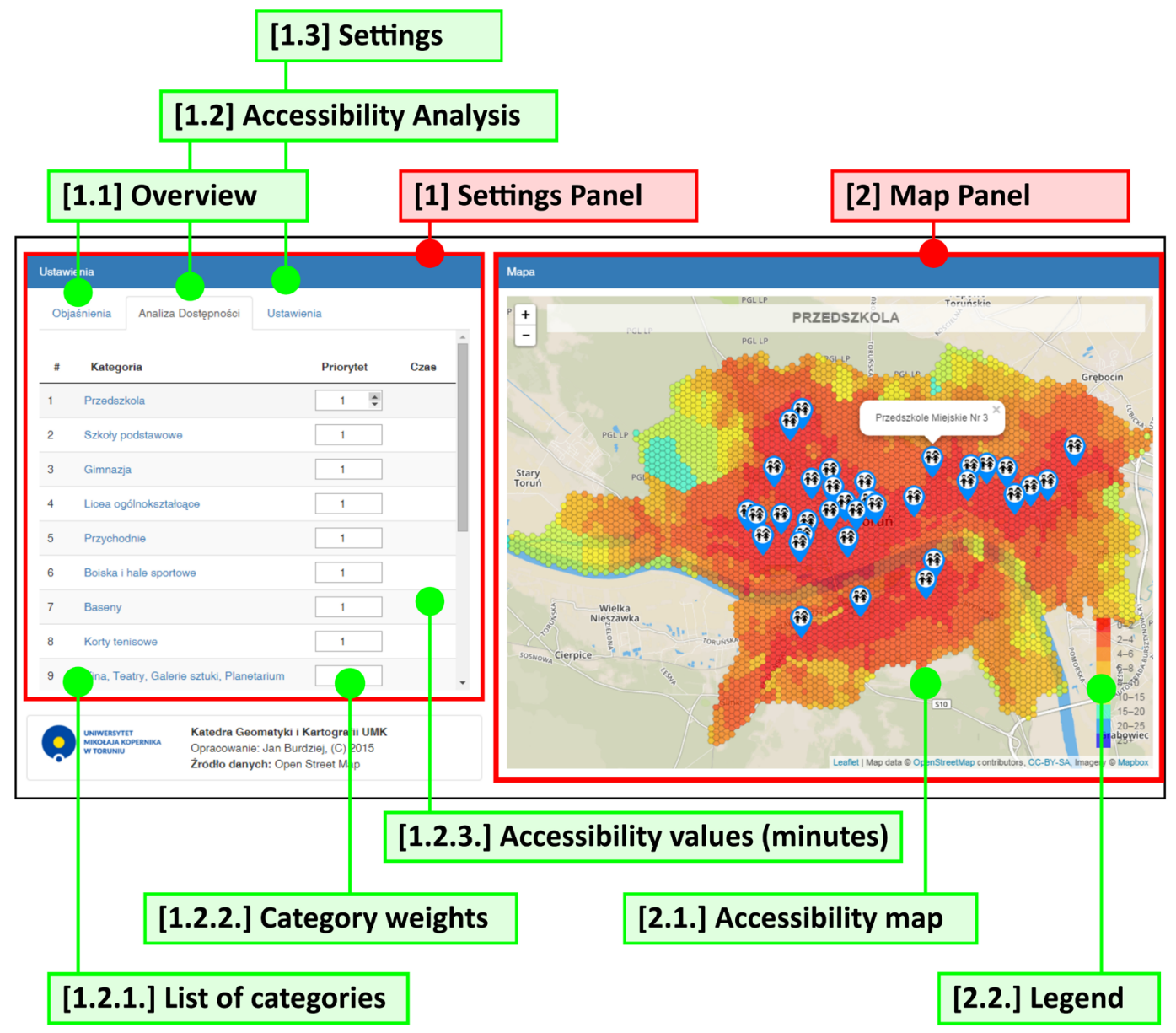

Figure 6. Prototype interface of the proposed web-based SDSS (source: own elaboration)

Web-based spatial decision support system

The final part of this study was to develop a prototype of a web-based spatial decision support system (SDSS) that allows users to perform analyses based on custom preferences. The prototype was developed using modern HTML, JavaScript and CSS technologies supported by the Leaflet JavaScript mapping library. A number of additional libraries were also used, such as leaflet-routing-machine.js (routing), jQuery (interface design), dataTables.js, chroma.js, and turf.js (creating dynamic colour ramps and classifiers)

The actual data was stored in a single geoJSON file containing all the hexagons with their accessibility values. Minimum travel times to all $16 \mathrm{POI}$ categories were assigned to each hexagon, along with the ID of each nearest amenity. Additionally, a second geoJSON file stored the location of all POls along with their attributes (such as ID, name and category).

The proposed SDSS consists of two main panels: Settings panel [1] and Map panel [2] (Fig. 6). The Settings Panel contains three tabs: Overview notes [1.1], Accessibility Analysis tab [1.2] and Settings tab [1.3]. The Overview tab contains information on the methodology used for the spatial accessibility analysis. The Accessibility tab [1.2] allows users to select different POI categories and display an interactive map presenting spatial accessibility (in minutes) to the nearest $\mathrm{POI}$ in the selected category. Additionally, the locations of all the relevant POls are displayed as point markers.
However, the main advantage of the system is its ability to perform a multi-criteria analysis. Users can define their own priorities (weightings from 0 to 10) for each category and calculate the weighted average accessibility for the whole study area. The map will be dynamically updated to show the spatial variation of this new statistic. The user can browse the map, compare different areas with regard to their spatial accessibility, change the transparency to see the background map and click on each hexagon to retrieve the exact travel times to all the selected categories. Once the hexagon is clicked, the nearest POls from all the selected categories will also be displayed.

The proposed SDSS supports users with some advanced cartographic settings: user-defined colour scales, as well as customizable class ranges for choropleth mapping. This allows users to define their own thresholds for the acceptable accessibility times to easily visualize the most suitable areas.

\section{Results and Discussion}

The primary results were the travel times (in minutes) to all public amenities calculated for each hexagon. Further analysis allowed the identification, for each hexagon, of the nearest public amenity in each category - that is, the shortest time to the nearest preschool, school, healthcare facility, and so on.

The results allow a detailed analysis of spatial accessibility in the area of Torun. Areas with good accessibility to different amenities, as well as areas with clearly weaker availability, were 
Table 1. Accessibility to public amenities in Toruń by POI categories

\begin{tabular}{|c|c|c|c|c|c|c|c|}
\hline \multirow{2}{*}{ Category } & \multirow{2}{*}{ POI count } & \multicolumn{5}{|c|}{ Average minimum travel time (minutes) } \\
\cline { 3 - 8 } & & \multicolumn{2}{|c|}{ Whole city area } & \multicolumn{4}{c|}{ Residential areas } \\
\cline { 3 - 8 } & & Max & Avg. & Rank & Max & \multicolumn{2}{c|}{ Avg. } \\
\hline Green areas & 1156 & 26.5 & 2.9 & 1 & 8.7 & 2.2 & 2 \\
\hline Public transport & 493 & 28.3 & 4.5 & 2 & 11.2 & 1.6 & 1 \\
\hline Healthcare & 35 & 29.6 & 7.1 & 3 & 16.0 & 3.6 & 6 \\
\hline Supermarkets & 69 & 29.9 & 7.2 & 4 & 14.6 & 3.3 & 3 \\
\hline Sports fields & 82 & 29.9 & 7.2 & 5 & 14.8 & 3.4 & 4 \\
\hline Preschools & 36 & 32.1 & 7.4 & 6 & 16.4 & 3.5 & 5 \\
\hline Primary schools & 24 & 33.1 & 7.5 & 7 & 14.5 & 3.8 & 7 \\
\hline Churches & 22 & 29.8 & 7.9 & 8 & 14.9 & 3.9 & 8 \\
\hline Secondary schools & 21 & 33.1 & 8.2 & 9 & 14.5 & 4.4 & 9 \\
\hline Swimming pools & 12 & 36.0 & 9.7 & 10 & 16.5 & 5.6 & 10 \\
\hline Shopping centres & 5 & 37.0 & 9.9 & 11 & 18.9 & 6.5 & 12 \\
\hline High schools & 12 & 37.2 & 10.0 & 12 & 19.8 & 6.1 & 11 \\
\hline Museums & 12 & 36.3 & 10.4 & 13 & 20.7 & 6.6 & 13 \\
\hline Tennis courts & 4 & 41.1 & 10.4 & 14 & 19.2 & 6.9 & 14 \\
\hline Cinemas and theatres & 6 & 36.4 & 12.1 & 15 & 20.8 & 8.8 & 15 \\
\hline City centre & 1 & 37.0 & 13.5 & 16 & 21.5 & 9.8 & 16 \\
\hline
\end{tabular}

(source: own elaboration based on OpenStreetMap data)

identified. Maps of spatial accessibility to each POI category were created and used to identify regions with lower accessibility.

It was identified that in the case of Torun, where nearly $30 \%$ of the area is occupied by forests (Kunz et al. 2012), the average accessibility values are greatly affected by these naturally less accessible areas. For this reason, all aggregated accessibility statistics (such as the average minimum accessibility to each POI type) were calculated separately for residential areas only. For example, the average minimum travel time to the nearest preschool calculated for the whole city area was 7.4 minutes, and only 3.5 minutes for residential areas.

The study shows that spatial accessibility to public amenities in Torun is relatively high. The average travel time to all POls was 8.5 minutes for the whole city area and only 5 minutes for residential areas. The most accessible category in Torun is the green areas, i.e. parks and forests located within the city boundaries. The average accessibility for the whole city area is 2.9 and 2.2 minutes respectively, which is mainly caused by the large forest areas located within the city boundaries (Tab. 1). In residential areas the most accessible are public transport stops (1.5 min), green areas (2.2 $\mathrm{min})$, supermarkets (3.3 $\mathrm{min})$, sports facilities (3.4 min) and preschools (3.5 min).

The research also identified the most accessible area, which is located approximately $2 \mathrm{~km}$ north of the traditional city centre (the old town). Spatial accessibility to the city centre is significantly lower in the eastern part of the city (on average $16 \mathrm{~min}$ ).

It was recognised that there is a good opportunity for locating a cultural and entertainment centre on the eastern edge of the city centre, which could potentially serve all the eastern districts that completely lack these kinds of amenities (Fig. 7).

An interesting correlation was observed with respect to educational facilities: the number of facilities is inversely proportional, while the tendency to concentrate near the city centre is directly proportional, to the level of education. In particular, high schools, which are located near the city centre, have lower accessibility compared to other schools, although the level is similar for all high schools. This means that there is high competition between these schools for students from all over the city, as none of the schools can attract students by offering them significantly better accessibility.

The level of accessibility for each category results from several factors - mainly the spatial accessibility of each individual $\mathrm{POI}$ within this category, as well as the total number of POls and their spatial distribution. One of the most spatially effective categories is churches - with a relatively low number of facilities, they achieve a high level of overall accessibility. This is because they are evenly distributed and typically located in the centres of residential areas (Fig. 8). This is an interesting example showing that even a smaller number of facilities can lead to high overall accessibility, provided that their spatial distribution is well planned and corresponds to social demand.

The methodology based on a hexagonal grid developed for this research proved to be an interesting approach for the analysis of accessibility. It has several advantages over other commonly used methods, such as raster-based cost-distance analysis or isochrone methods.

The proposed methodology incorporates modern road network data sources and routing algorithms, which can be applied to custom hexagonal sampling grids. The size of the grid can be adjusted based on the size of the study area and the intended spatial resolution of the study.

The proposed methodology does not require interpolating travel times, which is often the case in other accessibility analyses - for example, using isochrones. Moreover, it allows the inclusion of detailed road network constraints, such as turn restrictions, road connectivity and direction, all of which influence actual travel patterns and routes.

The outcome of the main accessibility analysis model (Fig. 4) was an extensive database of $9,339,070$ routes described by route distance, total travel time and IDs of Origins and 


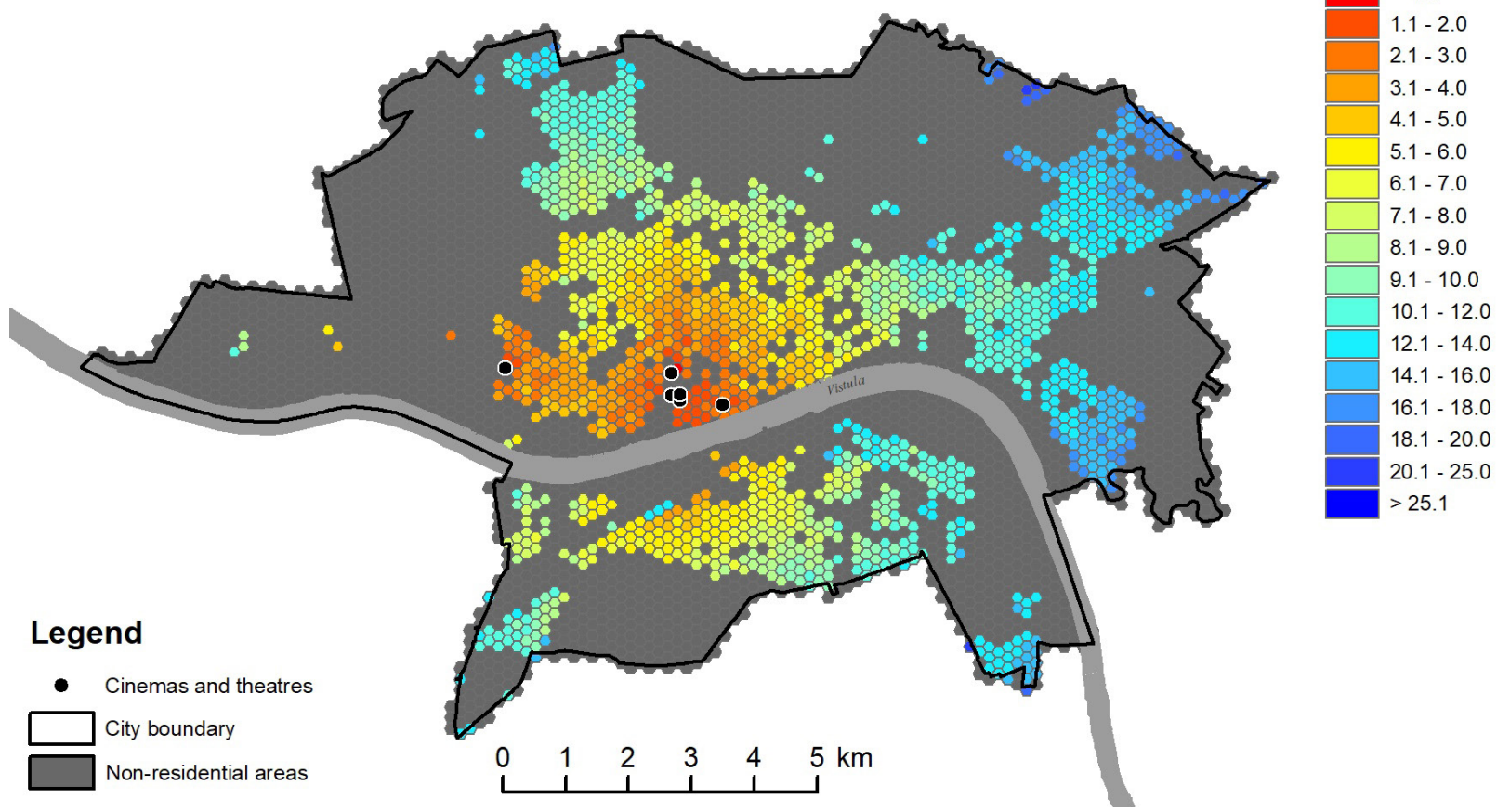

Figure 7. Spatial accessibility to cinemas and theatres (residential areas) (source: own elaboration)

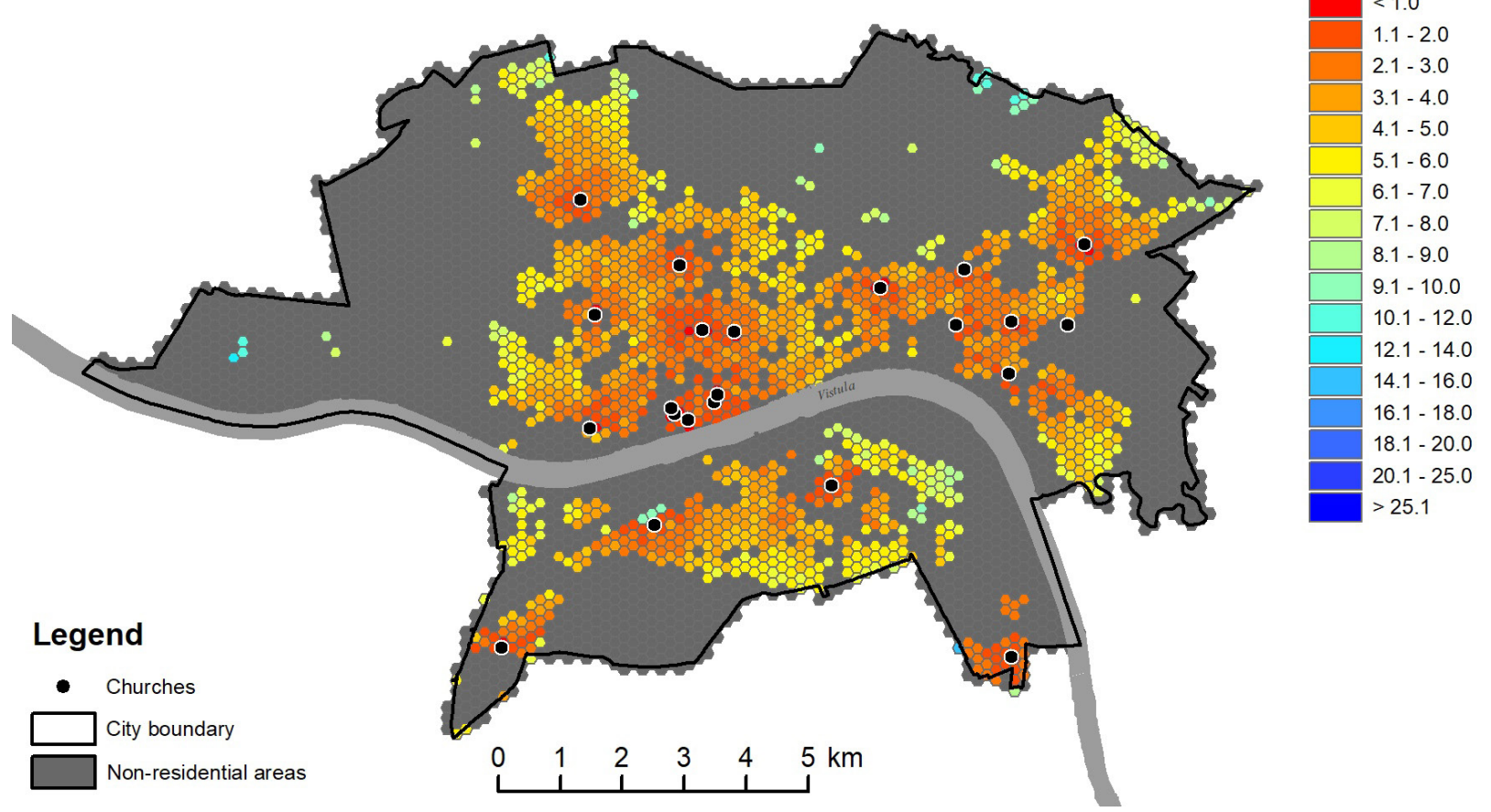

Figure 8. Spatial accessibility to churches (residential areas) (source: own elaboration) 


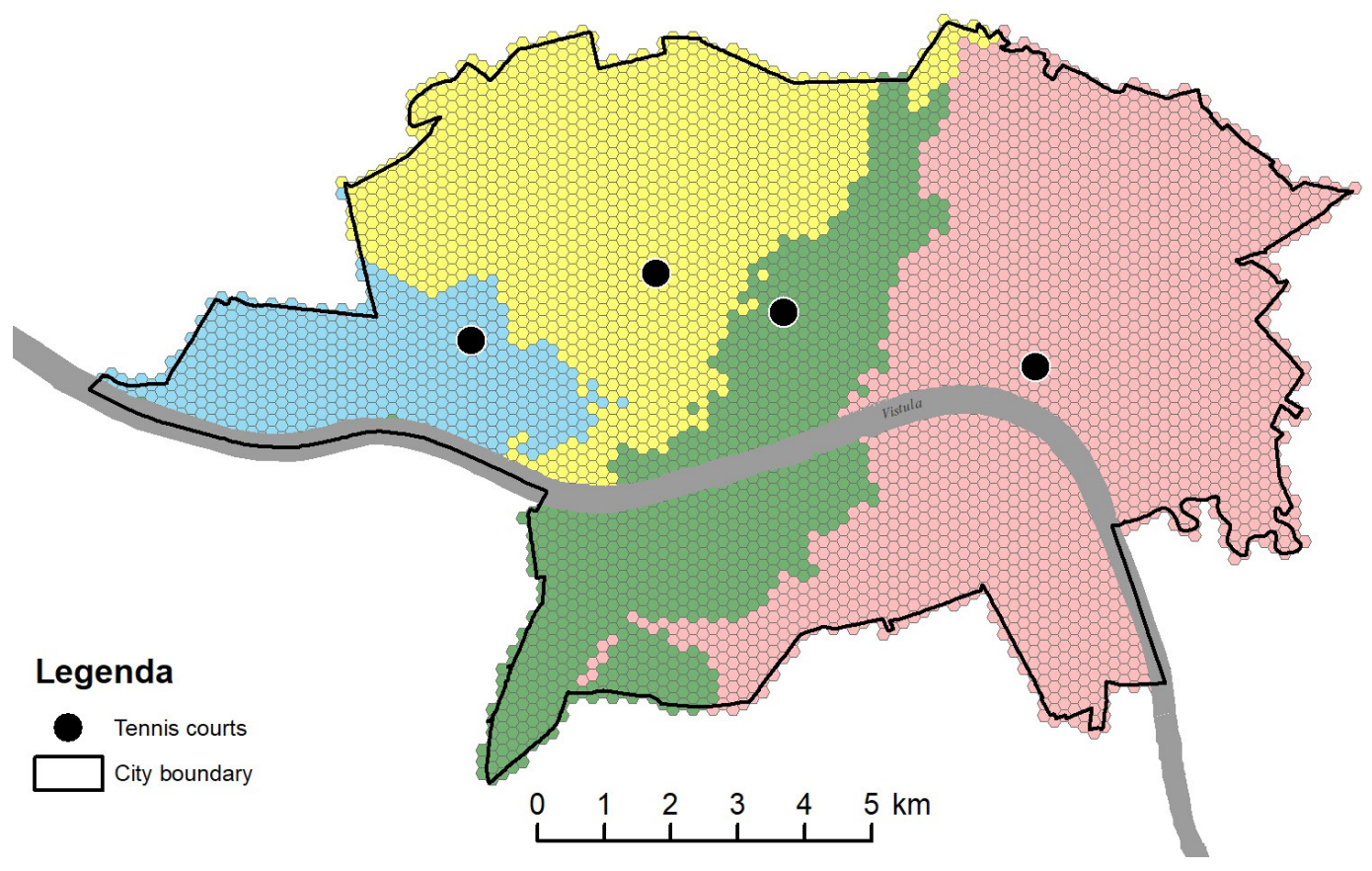

Tennis court service areas

$\mathrm{ID}=734$ $\mathrm{ID}=735$

$\mathrm{ID}=736$ $\mathrm{ID}=737$

Figure 9. Tennis court service areas (source: own elaboration)

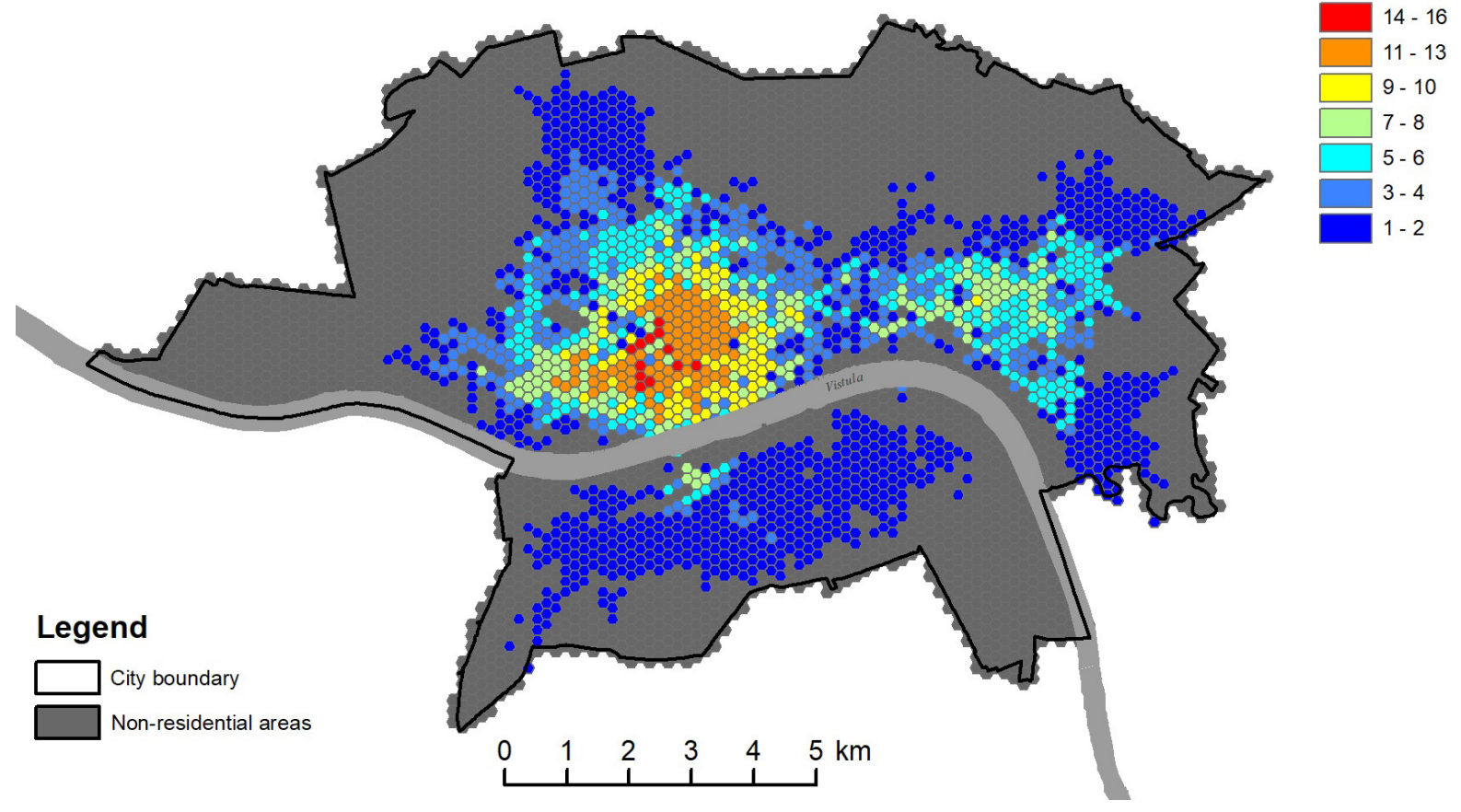

Figure 10. Number of preschools available within a 5 min. drive (source: own elaboration) 


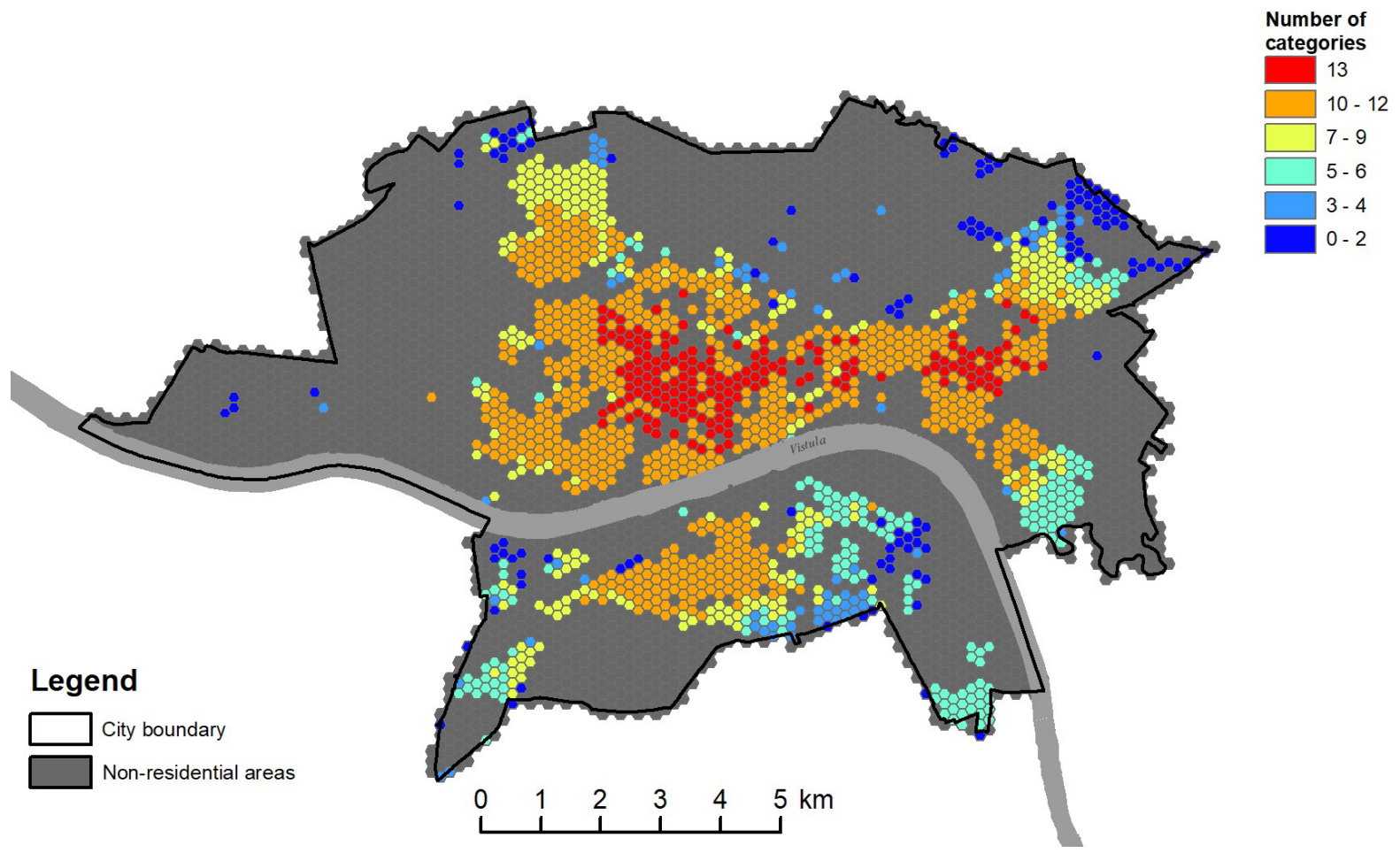

Figure 11. Number of POI categories available within a 5 min. drive (source: own elaboration)

Destinations. This database allowed not only the identification of the shortest travel time to the nearest POI for each hexagon, but also the delineation of service areas and evaluation of the number of different services available within a given time.

A short travel time to the nearest POI (e.g. preschool) is not the only accessibility measure that contributes to the attractiveness of a given area. Often, it is also the choice of different amenities that might be even more important. For example, one location may have a slightly shorter time to the nearest preschool than another location. However, the first location might have only one preschool within a given travel time (e.g. 10 minutes), while the second location might offer a choice of several preschools within just one extra minute. This variety gives parents higher chances of finding a place for their children in preschool, and offers them more choices (e.g. to select a preschool with a higher rating). The proposed methodology allowed the easy calculation of the number of specific POls within a defined travel time (Fig. 10).

Similarly, the variety of unique POI categories available within a given travel time can be retrieved directly from the calculated accessibility values (Fig. 11). When three 'central' categories were excluded from the analysis (i.e. city centre, cinemas and theatres, and museums), another potential 'city centre' was clearly identified in the eastern part of the city. This is the largest residential area, consisting mainly of blocks of flats, and the main source of commuters travelling on a daily basis to the city centre for work. Provided that new office buildings (generating workplaces) and some cultural facilities are located in this part of the city, the daily traffic could be significantly reduced.

\section{Conclusions}

In conclusion, it is clear that accessibility analysis can play an important role in better understanding and addressing some of the most important challenges of modern cities, such as traffic congestion, environmental quality and equal access to goods and services.

The results of this research show that the proposed methodology, based on a hexagonal sampling grid combined with network analysis, can be successfully applied to the spatial accessibility analysis of urban public amenities. The methodology has shown several advantages over other methods. It can be used to calculate various accessibility metrics simultaneously for example, the minimum travel time to selected POI categories, the number of different POI categories, the number of facilities available within a predefined time, and many others. It can also be used to analyse service areas and assess the spatial efficiency of public amenity distribution. It does not involve accessibility interpolation and takes full advantage of using network-based routing algorithms and road network datasets (such as Open Street Map).

Moreover, the accessibility values calculated in a hexagonal grid can be easily compared with other statistics, such as the socio-demographic profile of the urban population, the quality of the environment (e.g. air pollution or noise level), real estate prices, and so on.

However, it is important that smart geospatial tools are not reserved for city planners, but are made available to all citizens, allowing them to take informed decisions. GIS tools can significantly support spatial decisions taken by both citizens and municipal authorities, contributing to optimized site location, thus reducing transport needs and traffic congestion, improving the quality of the environment and overall quality of life.

Therefore, it is particularly important not only to invent new methods of measuring accessibility, but also to design new ways of sharing them with the community for the benefit of all stakeholders: citizens, local governments and businesses. The prototype of the web-based spatial decision support system 
proposed in this paper is just one example of this effort. Further research will focus on designing a generic spatial accessibility urban data model, allowing multi-disciplinary data assessment and developing a publicly available web-based system, which can be applied to the spatial accessibility analysis of any city.

\section{References}

Balfour, R \& Allen, J 2014, Local action on health inequalities: Improving access to green spaces, Public Health England, UCL Institute of Health Equity, London.

Beler, F 1997, 'The distribution of urban public services: the case of parks and recreational services in Ankara', Cities, vol. 14, iss. 6, pp. 353-361.

Bielecka, E \& Filipczak, A 2010, 'Zasady opracowywania map dostępności' [Principals of elaborating accessibility maps], Roczniki Geomatyki [Annals of Geomatics], vol. VIII, no. 6(42), pp.29-39.

Billaudeau, N, Oppert, J-M, Simon, C, Charreire, H, Casey, R, Salze, P, Badariotti, D, Banos, A, Weber, C, \& Chaix, B 2011, 'Investigating disparities in spatial accessibility to and characteristics of sport facilities: Direction, strength, and spatial scale of associations with area income', Health \& Place, vol. 17, no. 1, pp. 114-121.

Birch, CP, Oom, SP, \& Beecham, JA 2007, 'Rectangular and hexagonal grids used for observation, experiment and simulation in ecology', Ecological Modelling, vol. 206, no. 3-4, pp. 347-359.

Burdziej, J 2009, 'Multi-criteria spatial analysis of land accessibility for seismic operations', Roczniki Geomatyki [Annals of Geomatics], vol. 7, no. 2, pp. 23-31.

Burdziej, J 2016, 'Analiza dostępności przestrzennej za pomocą technologii GIS na przykładzie obiektów użyteczności publicznej w Toruniu' [Analysis of spatial accessibility using GIS technology on the example of public buildings in Torun], Prace Komisji Geografii Komunikacji PTG [Transport Geography Papers of Polish Geographical Society], vol. 2016, no. 19(2). Available from: <http://www.ejournals.eu/ PKGKPTG/2016/19(1)/art/8743/>. [27 April 2017].

Cabrera-Barona, P, Wei, C \& Hagenlocher, M 2016, 'Multiscale evaluation of an urban deprivation index: Implications for quality of life and healthcare accessibility planning', Applied Geography, vol. 70, pp. 1-10.

Carr, DB, Olsen, AR, \& White, D 1992, 'Hexagon mosaic maps for display of univariate and bivariate geographical data',Cartography and Geographic Information Systems, vol. 19, no. 4, pp. 228-236.

Chiesura, A 2004, 'The role of urban parks for the sustainable city', Landscape and Urban Planning, vol. 68, no. 1, pp. 129-138.

Comber, A, Brunsdon, C, \& Green, E 2008, 'Using a GISbased network analysis to determine urban greenspace accessibility for different ethnic and religious groups',Landscape and Urban Planning, vol. 86, no. 1, pp. 103-114.

Doi, K, Kii, M, \& Nakanishi, H 2008, 'An integrated evaluation method of accessibility, quality of life, and social interaction', Environment and Planning B: Urban Analytics and City Science, vol. 35, no. 6, pp. 1098-1116.

Farber, S, Morang, MZ, \& Widener, MJ 2014, 'Temporal variability

in transit-based accessibility to supermarkets', Applied Geography, vol. 53, pp. 149-159.

Fransen, K, Neutens, T, De Maeyer, P, \& Deruyter, G 2015, 'A commuter-based two-step floating catchment area method for measuring spatial accessibility of daycare centers', Health \& Place, vol. 32, pp. 65-73.
Galton, F 1881, 'On the construction of isochronic passage charts', Proceedings of the Royal Geographical Society, vol. 3, pp. 657-658.

Guagliardo, MF 2004, 'Spatial accessibility of primary care: concepts, methods and challenges', International journal of health geographics, vol. 3 , no. 1 .

Guzik, R 2003a, Przestrzenna dostępność szkolnictwa Ponadpodstawowego [Spatial availability of post-primary education]. Instytut Geografii i Gospodarki Przestrzennej Uniwersytetu Jagiellońskiego, Kraków.

Guzik, R 2003b,'Interpretacja przestrzennej dostępności szkół ponadpodstawowych w oparciu o metodę ilorazu potencjałów' [Interpretation of spatial accessibility of secondary schools based on the potential quotient method], in Problemy interpretacji wyników metod badawczych stosowanych w geografii społecznoekonomicznej i gospodarce przestrzennej [Problems of interpretation of the results of research methods applied in socio-economic geography and spatial economy], Wydawnictwo Naukowe Bogucki, Poznań, pp.101-110.

Hodge, DC 1997, 'Accessibility-related issues', Journal of Transport Geography, vol. 5, no. 1, pp. 33-34.

Hołowiecka, B \& Szymańska, D 2008, 'The changes in the functional urban region in the new socio-economic conditions in Poland. The case of Torun.', Bulletin of Geography (socioeconomic series), no. 9, pp. 63-78

Jia, P 2016, 'Developing a flow-based spatial algorithm to delineate hospital service areas', Applied Geography, vol. 75, pp. 137-143.

Komornicki, T, Śleszyński, P, Pomianowski, W, Rosik, P, Siłka, P \& Stępniak, M 2008, Opracowanie metodologii liczenia wskaźnika międzygałęziowej dostępności transportowej terytorium Polski oraz jego oszacowanie [Development of the counting methodology of the transport accessibility index of Poland and its estimation], Instytut Geografii i Przestrzennego Zagospodarowania im. Stanisława Leszczyckiego Polskiej Akademii Nauk, Warszawa. Available from: <http://www.pois.gov.pl/ AnalizyRaportyPodsumowania/Documents/2009.01.22 wskaznik_dostepnosci_POliS_opis.pdf>. [27 April 2017].

Kraft, S 2016, 'Measuring and modelling the spatial accessibility of public transport stops in GIS', Hungarian Geographical Bulletin, vol. 65, no. 1, pp. 57-69.

Kuhlthau, KA 2011, 'Measures of availability of health care services for children', Academic pediatrics, vol. 11, no. 3 , pp. S42-S48.

Kunz, M, Uscka-Kowalkowska, J, Przybylak, R, Kejna, M, Araźny, A \& Maszewski, R 2012, 'Zróżnicowanie klimatów lokalnych Torunia - założenia projektu i wstępne wyniki badań' [Diversity of local climate in Torun - outline of the project and preliminary results of investigations], Roczniki Geomatyki [Annals of Geomatics], vol. X, no. 3(53), pp. 85-94.

Kwan, MP \& Weber, J 2008, 'Scale and accessibility: Implications for the analysis of land use-travel interaction', Applied Geography, vol. 28, no. 2, pp. 110-123.

Larsen, K \& Gilliland, J 2008, 'Mapping the evolution of "food deserts" in a Canadian city: Supermarket accessibility 
in London, Ontario, 1961-2005', International Journal of Health Geographics, vol. 7, no. 1.

Levine, AS \& Feinholz, CL 2015, 'Participatory GIS to inform coral reef ecosystem management: Mapping human coastal and ocean uses in Hawaii', Applied Geography, vol. 59, pp. 60-69.

Lopez, E \& Greenlee, A 2016, 'An ex-ante analysis of housing location choices due to housing displacement: The case of Bristol Place', Applied Geography, vol. 75, pp. 156-175.

Lotfi, S \& Koohsari, MJ 2009, 'Measuring objective accessibility to neighborhood facilities in the city (A case study: Zone 6 in Tehran, Iran)', Cities, vol. 26, no. 3, pp. 133-140.

Luo, W \& Wang, F 2003, 'Measures of spatial accessibility to health care in a GIS environment: synthesis and a case study in the Chicago region', Environment and Planning B: Planning and Design, vol. 30, no. 6, pp. 865-884.

McGrail, MR \& Humphreys, JS 2014a, 'Measuring spatial accessibility to primary health care services: Utilising dynamic catchment sizes', Applied Geography, vol. 54, pp. 182-188.

McGrail, MR \& Humphreys, JS 2014b, 'Measuring spatial accessibility to primary health care services: Utilising dynamic catchment sizes', Applied Geography, vol. 54, pp. 182-188.

Nelson, A 2008, Estimated travel time to the nearest city of 50,000 or more people in year 2000. Available from: <http:// forobs.jrc.ec.europa.eu/products/gam/>. [27 April 2017].

Neutens, T 2015, 'Accessibility, equity and health care: review and research directions for transport geographers', Journal of Transport Geography, vol. 43, pp. 14-27.

OpenStreetMap Wiki | OSM XML 2015. Available from: <http:// wiki.openstreetmap.org/wiki/OSM_XML>. [2 April 2015].

Osborne, H 2014, 'Commuting makes you 'unhappy and anxious', says ONS', The Guardian 12 February. Available from: <http://www.theguardian.com/money/2014/feb/12/ commuting-unhappy-anxious-ons>. [20 November 2015].

Penck, A 1887, 'Isochronenkarte der österreichisch-ungarischen Monarchie' in Die deutsche Rundschau für Geographie und Statistik, vol. IX, A. Hartleben's Verlag, Wien.

Perkins, HA, Heynen, N \& Wilson, J 2004, 'Inequitable access to urban reforestation: the impact of urban political economy on housing tenure and urban forests', Cities, vol. 21, no. 4, pp. 291-299.

Pifczyk, S 2014, Jak daleko potrafimy dojeżdżać do pracy? Sprawdziliśmy [How far are we able to commute to work? We checked]. Available from: <http://biqdata.pl/dojazdydopracy-polakow>. [20 November 2015].

Rosero-Bixby, L 2004, 'Spatial access to health care in Costa Rica and its equity: a GIS-based study', Social Science \& Medicine, vol. 58, no. 7, pp. 1271-1284

Rosik, P 2012, Dostępność lądowa przestrzeni Polski w wymiarze europejskim [Surface accessiblility of the space of Poland in the European dimension], PAN IG i PZ, Warszawa.

Salonen, M 2014, Analysing spatial accessibility patterns with travel time and distance measures: novel approaches for rural and urban contexts, Doctoral thesis, University of Helsinki.

Somarriba, N \& Pena, B 2008, 'Quality of life and subjective welfare in Europe: an econometric analysis'. Available from: <https://papers.ssrn.com/sol3/papers.cfm?abstract id $=1319327>$. [4 April 2017].

Spiekermann, K \& Neubauer, J 2002, 'European accessibility and peripherality: Concepts, models and indicators', Nordregio WP, vol. 9

Stępniak, M 2013, 'Wykorzystanie metody 2SFCA w badaniach dostępności przestrzennej usług medycznych' [The application of the two-step floating catchment area metod to the studies of accessibility of healthcare services], Przegląd Geograficzny [Polish Geographical Review], vol. 85, no. 2, pp. 199-218.

Tang, P, Xiang, J, Luo, J, \& Chen, G 2017, 'Spatial accessibility analysis of primary schools at the county level based on the improved potential model: case study of Xiantao City, Hubei Province', Progress in Geography, vol. 36, no. 6, pp. 697-708.

Taylor, Z 1999, Przestrzenna dostępność miejsc zatrudnienia, kształcenia i usług a codzienna ruchliwość ludności wiejskiej [Spatial availability of employment, education and services and the daily mobility of the rural population], Continuo, Wrocław.

Vandenbulcke, G, Steenberghen, T \& Thomas, I 2009, 'Mapping accessibility in Belgium: a tool for land-use and transport planning?', Journal of Transport Geography, vol. 17, no. 1, pp. 39-53.

Wang, J, Kwan, M-P, \& Ma, L 2014, 'Delimiting service area using adaptive crystal-growth Voronoi diagrams based on weighted planes: A case study in Haizhu District of Guangzhou in China', Applied Geography, vol. 50, pp. 108-119.

Weber, J 2006, 'Reflections on the future of accessibility', Journal of Transport Geography, vol. 14, no. 5, pp. 399-400.

Yiannakoulias, N, Bland, W \& Svenson, LW 2013, 'Estimating the effect of turn penalties and traffic congestion on measuring spatial accessibility to primary health care', Applied Geography, vol. 39, pp. 172-182.

Zhu, X \& Liu, S 2004, 'Analysis of the impact of the MRT system on accessibility in Singapore using an integrated GIS tool', Journal of Transport geography, vol. 12, no. 2, pp. 89-101.

Zhu, X, Liu, S \& Yeow, MC 2006, 'A GIS-based multi-criteria analysis approach to accessibility analysis for housing development in Singapore', Proceedings of SSC 2005 Spatial Intelligence, Innovation and Praxis: The national biennial Conference of the Spatial Sciences Institute, September, 2005. Melbourne: Spatial Sciences Institute. Available from: $<$ https://www.researchgate.net/publication/242450034>. [20 April 2017].

Zhu, X, Liu, S \& Yeow, MC 2006, 'Accessibility analysis for housing development in Singapore with GIS and multicriteria analysis methods', Applied GIS, vol. 2, no. 2, pp. 13.1-13.12.

Zimmermann, E 2010, OpenStreetMap in Arc GIS - Automatisierte Datenaufbereitung für Netzwerkanalysen, Hochschule Karlsruhe, Kranzberg. 